\title{
How Much (More) Should CEOs Make? A Universal Desire for More Equal Pay
}

\section{Citation}

Kiatpongsan, Sorapop, and Michael I. Norton. "How Much (More) Should CEOs Make? A Universal Desire for More Equal Pay." Perspectives on Psychological Science (forthcoming).

\section{Permanent link}

http://nrs.harvard.edu/urn-3:HUL.InstRepos:13348081

\section{Terms of Use}

This article was downloaded from Harvard University's DASH repository, and is made available under the terms and conditions applicable to Open Access Policy Articles, as set forth at http:// nrs.harvard.edu/urn-3:HUL.InstRepos:dash.current.terms-of-use\#OAP

\section{Share Your Story}

The Harvard community has made this article openly available.

Please share how this access benefits you. Submit a story.

\section{Accessibility}




\title{
How Much (More) Should CEOs Make?
}

\section{A Universal Desire for More Equal Pay}

\begin{abstract}
Sorapop Kiatpongsan ${ }^{1,2}$ and Michael I. Norton ${ }^{3}$
\end{abstract}
In Press, Perspectives on Psychological Science

${ }^{1}$ Faculty of Medicine, Chulalongkorn University, Bangkok, Thailand

${ }^{2}$ Sasin Graduate Institute of Business Administration of Chulalongkorn University, Bangkok, Thailand

${ }^{3}$ Harvard Business School, Boston, MA, USA 


\begin{abstract}
Do people from different countries and different backgrounds have similar preferences for how much more the rich should earn than the poor? Using survey data from 40 countries $(N=$ 55,238), we compare respondents' estimates of the wages of people in different occupations chief executive officers, cabinet ministers, and unskilled workers - to their ideals for what those wages should be. We show that ideal pay gaps between skilled and unskilled workers are significantly smaller than estimated pay gaps, and that there is consensus across countries, socioeconomic status, and political beliefs for ideal pay ratios. Moreover, data from 16 countries reveals that people dramatically underestimate actual pay inequality. In the United States where underestimation was particularly pronounced - the actual pay ratio of CEOs to unskilled workers (354:1) far exceeded the estimated ratio (30:1) which in turn far exceeded the ideal ratio (7:1). In sum, respondents underestimate actual pay gaps, and their ideal pay gaps are even further from reality than those underestimates.
\end{abstract}

\title{
Keywords
}

inequality, fairness, justice, income, wage, cross-cultural 
Across 26 developed countries, the average minimum wage increased by just $0.7 \%$ in 2010 and actually decreased by $0.6 \%$ in 2011 (ILO, 2013), in sharp contrast to the steady rise in compensation for executives (Morgenson, 2013). Indeed, the ratio of the pay of an average chief executive officer (CEO) to an average employee in the United States increased from 20:1 in 1965 to 354: 1 in 2012 (AFL-CIO, 2013; Hargreaves, 2014; Mishel \& Sabadish, 2013), ignoring the advice of management guru Peter Drucker, who suggested that exceeding a 20:1 ratio would increase employee resentment and decrease morale (McGregor, 2013). Not surprisingly, 2013 saw worker protests and strikes in cities such as New York, Chicago, Detroit and Seattle demanding an increase in the minimum wage (Greenhouse, 2013); one survey in 2013 revealed that $76 \%$ of Americans favored raising the federal minimum wage to $\$ 9.00$ (Dugan, 2013). Partly in response, President Obama increased the minimum wage for federal contractors from \$7.25 to \$10.10 in early 2014 (Wolfgang, 2014). At the other end of the pay scale, public support for initiatives to cap CEO pay has also increased in recent years (Beardsley, 2013; Burak, 2013; McGregor, 2013).

Desires for increases in the minimum wage and caps to executive pay offer some indirect evidence that at least some people wish for smaller pay gaps, but what size gaps do people desire? People have a general aversion to outcomes that surpass some threshold of fairness (Fehr \& Schmidt, 1999) and recent research suggests that both Americans and Australians desire a more equal distribution of wealth (Norton \& Ariely, 2011; Norton, Neal, Govan, Ariely, \& Holland, in press) but little is known about people's preferences for the distribution of wages, and whether those preferences are universally held across people from different countries and backgrounds. Income differs from wealth in that wages or earnings are direct compensation for an individual's labor and productivity whereas wealth reflects both earnings and accumulated 
wealth (e.g., through investments and inheritance). Understanding people’s ideal distributions of wealth can inform policies related to wealth regulation such as property and inheritance taxes; understanding people's ideal pay ratios - and assessing whether these ideal ratios are commonlyheld - can inform policies regarding wage regulation, progressive taxation of income, and other interventions that might affect pay gaps.

Using survey data from 40 countries, we compare people’s perceptions (i.e., estimates) of the current wage disparities among people in different occupations to their preferences (i.e., ideals) for what they feel these gaps in pay should be. These occupations were a chairman of a large national corporation (CEO), a cabinet minister, and an unskilled worker. Data were retrieved from the latest International Social Survey Programme (ISSP) published in December 2012 (ISSP Social Inequality IV conducted in 2009). Respondents from 40 countries ( $N=$ 55,238, $M_{\text {age }}=46.8, S D=15.8 ; 54.7 \%$ female) completed the survey (see Table 1 for complete list).

The ISSP working principles require that the sample from each member country is a nationally representative random sample of the adult population, designed to achieve a norm of 1,400 cases (with a minimum of 1,000 cases) for each member country. More information about the ISSP and ISSP Social Inequality IV can be found at the ISSP website (ISSP, 2009). The statistical software package SPSS 21.0 (SPSS Inc., Chicago, IL) was used for all data analyses. Statistical significance was determined at $p<.05$.

\section{People Want Smaller Pay Gaps}

Respondents were asked to estimate how much a chairman of a large national company (CEO), a cabinet minister in the national government, and an unskilled factory worker actually 
earn (“estimated pay”). Then, they reported how much these people should earn (“ideal pay”). These responses were open-ended: respondents stated the income that they believed members of each occupation actually earned and should earn. We calculated pay ratios using the pay of an unskilled factory worker as the denominator; e.g., the estimated pay ratio of CEO pay to unskilled worker pay is equal to the estimated pay of a CEO divided by the estimated pay of an unskilled worker. That is:

Estimated pay ratio of CEOs to unskilled workers

\begin{tabular}{|c|c|}
\hline & Estimated CEO pay \\
\hline$=$ & Estimated unskilled \\
\hline
\end{tabular}

Pay ratios were calculated for both ratios of estimated incomes (“estimated pay ratios”) and ratios of ideal incomes (“ideal pay ratios”); we report median ratios instead of mean ratios because distributions of all estimated and ideal pay ratios did not pass the normality test.

Across the full sample, the estimated pay ratio of CEOs to unskilled workers was 10.0 (interquartile range $=20.0$ ), whereas the ideal ratio was 4.6 (interquartile range $=7.5$; see solid and dotted lines in Figure 1a). The estimated pay ratio of cabinet ministers to unskilled workers was 8.3 (interquartile range $=10.0$ ), whereas the ideal ratio was 3.6 (interquartile range $=4.4$; see solid and dotted lines in Figure 1b). The pairwise difference between the estimated and ideal pay ratios was significant for both comparisons (Related-Samples Wilcoxon Signed Rank Test (non-parametric test); ps <.001). Note that both estimated and ideal gaps were higher for CEOs than for cabinet ministers - suggesting a general belief that CEOs should be paid relatively more than high-level government officials - but that in both cases, ideal pay ratios were smaller than estimated pay ratios.

\section{Consensus across Countries}


Estimated pay ratios of CEOs to unskilled workers ranged from 3.7 (in Denmark) to 41.7 (in South Korea), whereas ideal ratios ranged from 2.0 (in Denmark) to 20.0 (in Taiwan). The pairwise differences between the estimated and ideal pay ratios of CEOs to unskilled workers were significant in all 40 countries (Related-Samples Wilcoxon Signed Rank Test (nonparametric test); $p s<.001$; Figure 1a).

How do respondents' estimated and ideal pay ratios compare to actual current pay ratios? In the United States in 2012, for example, the average yearly compensation for CEOs of S\&P 500 companies was $\$ 12.3$ million, about 354 times the pay for an average worker of $\$ 35,000$ (AFL-CIO, 2013; Hargreaves, 2014). American respondents $(n=1,581)$ in our data estimated the ratio of estimated incomes of CEOs to unskilled workers to be 29.6, demonstrating that Americans drastically underestimated the gap in actual incomes between CEOs and unskilled workers.

We compared the estimated pay ratio of CEOs to unskilled workers with the actual pay ratio for the 16 countries where data on the pay of CEOs and the pay of average workers are available (AFL-CIO, 2013; see Table 1 for complete list). In all 16 countries, the estimated pay ratio of CEOs to unskilled workers was significantly lower than the actual ratio (One-Sample Wilcoxon Signed Rank Test (non-parametric test); $p s<.001$; Figure 2). Note that Figure 2 includes the estimated and ideal data from Figure 1a, but both are so much smaller than actual pay ratios that they are nearly invisible.

Again by way of comparison, estimated pay ratios of cabinet ministers to unskilled workers ranged from 2.5 (in Norway) to 25.7 (in South Africa), whereas ideal ratios ranged from 2.0 (in Norway) to 10.0 (in South Africa). The pairwise differences between the estimated and 
ideal pay ratios of cabinet ministers to unskilled workers were significant in all countries (Related-Samples Wilcoxon Signed Rank Test (non-parametric test); $p s<.001$; Figure 1b).

\section{Consensus across Demographic Groups}

Respondents reported their age (in years), highest level of education completed (no formal education, lowest formal education, above lowest formal education, secondary school, above secondary school, university degree), and subjective socioeconomic status. For subjective socioeconomic status, respondents used a 10-point scale $(10=$ the top; 1 = the bottom $)$ to answer: In our society there are groups which tend to be towards the top and groups which tend to be towards the bottom. Below is a scale that runs from top to bottom. Where would you put yourself now on this scale?

We grouped respondents into three age groups: less than 35 years old, 35-54 years old and 55 years old and above. We grouped respondents into six groups by their education. For subjective socioeconomic status, we grouped respondents into five groups (quintiles): those who answered 1 or 2 were classified as the bottom (poorest) 20\%, 3 or 4 the second $20 \%, 5$ or 6 the middle $20 \%, 7$ or 8 the fourth $20 \%$, and 9 or 10 the top (richest) $20 \%$.

In each subgroup by age, by education or by subjective socioeconomic status, there were significant pairwise differences between (1) the estimated and ideal pay ratios of CEOs to unskilled workers and (2) the estimated and ideal pay ratios of cabinet ministers to unskilled workers (Related-Samples Wilcoxon Signed Rank Test (non-parametric test); $p s<.001$ for all comparisons and for all subgroups; Table 2.)

Table 2 also reveals interesting variation in estimated and ideal pay ratios across subgroups. For example, respondents who identified their socioeconomic status as in the bottom 
20\% estimated a larger pay gap between CEOs and unskilled workers (11.4:1) than respondents who identified themselves as in the top $20 \%$ (10.0:1). In contrast, ideal ratios for the bottom $20 \%$ were smaller than for the top 20\% (4.3:1 and 5.0:1). As a result, the gap between estimated and ideal ratios for the bottom 20\% was larger than the gap for the top 20\%, suggesting that the bottom 20\% may be relatively less satisfied with the current gaps in pay; both groups, however, agreed that ideal pay gaps should be much smaller than their estimated gaps.

\section{Consensus across Political Beliefs}

Respondents reported their political party affiliation, and were classified as far left, left, central, right, or far right. Respondents also stated their positions or answered questions assessing their beliefs about inequality: Differences in income in <country> are too large (strongly agree, agree, neither agree nor disagree, disagree, strongly disagree); you earn <...> than you deserve (much less than I deserve, less than I deserve, what I deserve, more than I deserve, much more than I deserve).

In each subgroup by political affiliation or by beliefs in inequality, there were significant pairwise differences between (1) the estimated and ideal pay ratios of CEOs to unskilled workers and (2) the estimated and ideal pay ratios of cabinet ministers to unskilled workers (RelatedSamples Wilcoxon Signed Rank Test (non-parametric test); ps <.001 for all comparisons and for

all subgroups; Table 2). Note, for example, that respondents who “strongly agreed” that differences in income were too large estimated a much larger pay gap between CEOs and unskilled workers (12.5:1) than respondents who "strongly disagreed” (6.7:1; Table 2). Yet, the ideal ratios for both groups were strikingly similar (4.7:1 and 4.8:1), suggesting that whether 
people agree or disagree that current pay gaps are too large, they agree that ideal gaps should be smaller.

\section{Consensus across Beliefs in Factors Determining Pay}

Respondents stated their opinions about factors determining what pay should be: how much responsibility goes with the job - how important do you think that ought to be in deciding pay? (essential, very important, fairly important, not very important, not important at all); how well he or she does the job - how important should that be in deciding pay? (essential, very important, fairly important, not very important, not important at all); how hard he or she works at the job - how important should that be in deciding pay? (essential, very important, fairly important, not very important, not important at all).

In each subgroup with differing beliefs in factors determining pay, there were significant pairwise differences between (1) the estimated and ideal pay ratios of CEOs to unskilled workers and (2) the estimated and ideal pay ratios of cabinet ministers to unskilled workers (RelatedSamples Wilcoxon Signed Rank Test (non-parametric test); ps <.001 for all comparisons and for all subgroups; Table 2).

\section{Changing the Wage Gap}

These results demonstrate that people with varying demographic profiles and differing beliefs about inequality and factors determining pay share a common desire for smaller gaps in incomes between skilled and unskilled workers'. The preference for greater pay equality between CEOs’ and unskilled workers’ and between cabinet ministers’ and unskilled workers’ held across all 40 countries in our sample. In addition, in the 16 countries for which we obtained actual pay 
gaps between CEOs and unskilled workers, actual gaps were larger than estimated gaps which were larger than ideal gaps.

Overall, respondents estimated the pay ratios of a CEO and cabinet minister to an unskilled worker to be 10.0 and 8.3, but reported that the ideal ratios should be more equal (4.6 and 3.6). The differences between these two sets of ratios show both the direction and the magnitude of preferences for ideal pay ratios. Importantly, respondents did believe that skilled workers deserved more pay than unskilled workers - even their ideal ratios still reflected a desire for skilled laborers to earn more. Indeed, the current wages of CEOs and cabinet ministers at least in part reflect a high demand for and a limited supply of these skilled workers. Still, while our findings suggest that people around the world believe that skilled workers should earn more than unskilled workers, they also feel that the ideal gap should be smaller than they believe it to be.

These results offer guidance for policymakers seeking to understand lay attitudes toward income inequality. Our results, in aggregate and stratified by age, level of education, socioeconomic status, political affiliation, and attitudes towards inequality and pay, suggest that most people desire greater equality in pay. And although it is unlikely that the ratio of incomes of CEO to unskilled workers in the United States will decrease from 354:1 to 7:1 in the short term, mechanisms to make these ratios more transparent offer an initial step. In fact, the Securities and Exchange Commission (SEC) voted to propose a rule requiring companies to disclose this information (AFL-CIO, 2013; McGregor, 2013).

Some countries have taken the next step and are attempting to decrease pay ratios. In Switzerland, for example, the Social Democratic Party successfully collected 100,000 signatures 
and proposed a cap of the pay ratio of CEOs to the lowest paid workers at 12 (Beardsley, 2013). Indeed, a national survey of Americans showed that 61\% supported this type of cap on CEO compensation (Burak, 2013). We note that such caps can come with risks: in the United States, Ben \& Jerry's implemented a 5 to 1 ratio for 16 years, but were forced to abandon the policy in 1995 when they were unable to find an executive willing to accept the cap (Weiss, 2013).

\section{Conclusion}

These results demonstrate a strikingly consistent belief that the gaps in incomes between skilled and unskilled workers should be smaller than people believe them to be - and much smaller than these gaps actually are. The consensus that income gaps between skilled and unskilled workers should be smaller holds in all subgroups of respondents regardless of their age, education, socioeconomic status, political affiliation and opinions on inequality and pay. As a result, they suggest that - in contrast to a belief that only the poor and members of left-wing political parties desire greater income equality - people all over the world, and from all walks of life, would prefer smaller pay gaps between the rich and poor. 


\section{Declaration of Conflicting Interests}

The authors declared that they had no conflicts of interest with respect to their authorship or the publication of this article. 


\section{References}

AFL-CIO. (2013). CEO-to-Worker Pay Ratios Around the World. Retrieved March 31, 2014, from http://www.aflcio.org/Corporate-Watch/CEO-Pay-and-You/CEO-to-Worker-PayGap-in-the-United-States/Pay-Gaps-in-the-World\#_ftn1

Beardsley, E. (2013). As Inequality Grows, Swiss To Vote On Curbing Executive Pay. Retrieved January 30, 2014, from http://www.npr.org/blogs/parallels/2013/11/22/246678622/swiss-inequality-is-growingwould-curbing-exec-pay-matter

Burak, E. (2013). The social maximum: American attitudes toward extremely high incomes. Research in Social Stratification and Mobility, 31, 18.

Dugan, A. (2013). Most Americans for Raising Minimum Wage. Retrieved February 24, 2014, from http://www.gallup.com/poll/165794/americans-raising-minimum-wage.aspx

Fehr, E., \& Schmidt, K. (1999). A theory of fairness, competition, and cooperation. Quarterly Journal of Economics, 114(3), 52.

Greenhouse, S. (2013). Fighting Back Against Wretched Wages, New York Times. Retrieved July 31, 2013. from http://www.nytimes.com/2013/07/28/sunday-review/fighting-backagainst-wretched-wages.html?hp\&pagewanted=all\&_r=0

Hargreaves, D. (2014). Can We Close the Pay Gap? Retrieved March 31, 2014, from http://opinionator.blogs.nytimes.com/2014/03/29/can-we-close-the-paygap/?_php=true\&_type=blogs\&hp\&rref=opinion\&_r=0

ILO. (2013). Global Wage Report 2012/13: International Labour Organization. ISSP. (2009). ISSP 2009 Social Inequality IV. Retrieved March 1, 2013, from http://www.gesis.org/en/issp/issp-modules-profiles/social-inequality/2009/ 
McGregor, J. (2013). What's the right ratio for CEO-to-worker pay? Retrieved March 2014, 2014, from http://www.washingtonpost.com/blogs/on-leadership/wp/2013/09/19/whatsthe-right-ratio-for-ceo-to-worker-pay/

Mishel, L., \& Sabadish, N. (2013). CEO Pay in 2012 Was Extraordinarily High Relative to Typical Workers and Other High Earners: Economic Policy Institute.

Morgenson, G. (2013, June 29). An Unstoppable Climb in C.E.O. Pay, New York Times.

Retrieved from http://www.nytimes.com/2013/06/30/business/an-unstoppable-climb-inceo-pay.html?pagewanted=all\&_r=0

Norton, M. I., \& Ariely, D. (2011). Building a Better America--One Wealth Quintile at a Time. Perspectives on Psychological Science, 6(1), 9-12.

Norton, M. I., Neal, D. T., Govan, C. L., Ariely, D., \& Holland, E. (in press). The not-socommon- wealth of Australia: Evidence for a cross-cultural desire for a more equal distribution of wealth. Analyses of Social Issues and Public Policy.

Weiss, M. (2013). A Sweet Solution to the Sticky Wage Disparity Problem. Retrieved 2014, March 27, from http://abcnews.go.com/Business/companies-follow-ben-jerrys-leadwages/story?id=19920634

Wolfgang, B. (2014). Because he says so: Acting alone, Obama boosts minimum wage for contractors. Retrieved April 24, 2014, from http://www.washingtontimes.com/news/2014/feb/12/obama-raise-minimum-wage-1010hour-federal-contrac/?page=all 
Table 1. List of countries.

Estimated and Ideal Wages Actual Wages

(40 countries)

(16 countries)

\begin{tabular}{|c|c|c|}
\hline Africa & South Africa & \\
\hline Asia & $\begin{array}{l}\text { China, Cyprus, Israel, Japan, } \\
\text { Philippines, South Korea, } \\
\text { Taiwan, and Turkey }\end{array}$ & Israel and Japan \\
\hline Australia / Oceania & Australia and New Zealand & Australia \\
\hline Europe & $\begin{array}{l}\text { Austria, Belgium, Bulgaria, } \\
\text { Croatia, Czech Republic, } \\
\text { Denmark, Estonia, Finland, } \\
\text { France, Germany, Hungary, } \\
\text { Iceland, Italy, Latvia, Norway, } \\
\text { Poland, Portugal, Russia, } \\
\text { Slovak Republic, Slovenia, } \\
\text { Spain, Sweden, Switzerland, } \\
\text { Ukraine, and United Kingdom }\end{array}$ & $\begin{array}{l}\text { Austria, Czech Republic, Denmark, } \\
\text { France, Germany, Norway, Poland, } \\
\text { Portugal, Spain, Sweden, Switzerland } \\
\text { and United Kingdom }\end{array}$ \\
\hline North America & United States & United States \\
\hline South America & $\begin{array}{l}\text { Argentina, Chile and } \\
\text { Venezuela }\end{array}$ & \\
\hline
\end{tabular}


Table 2. Estimated and ideal pay ratios of skilled to unskilled workers by respondents' demographics and beliefs.

\begin{tabular}{|c|c|c|c|c|}
\hline & \multicolumn{2}{|c|}{$\begin{array}{c}\text { CEOs versus } \\
\text { unskilled workers }\end{array}$} & \multicolumn{2}{|c|}{$\begin{array}{l}\text { Cabinet ministers versus } \\
\text { unskilled workers }\end{array}$} \\
\hline & Estimated & Ideal & Estimated & Ideal \\
\hline \multicolumn{5}{|l|}{ Demographics } \\
\hline \multicolumn{5}{|l|}{ Age (\%) } \\
\hline$<35(28)$ & 8.9 & 4.0 & 8.3 & 3.3 \\
\hline $35-54$ (37) & 10.0 & 4.6 & 8.3 & 3.6 \\
\hline 55 and above (34) & 12.5 & 5.0 & 8.3 & 4.0 \\
\hline \multicolumn{5}{|l|}{ Education (\%) } \\
\hline No formal education (5) & 10.0 & 5.0 & 10.0 & 5.0 \\
\hline Lowest formal education (16) & 10.0 & 4.0 & 9.3 & 3.8 \\
\hline Above lowest formal education (20) & 10.0 & 4.0 & 8.6 & 3.3 \\
\hline Secondary school (27) & 10.0 & 4.5 & 9.0 & 3.6 \\
\hline Above secondary school (15) & 11.5 & 5.0 & 7.5 & 3.3 \\
\hline University degree (17) & 12.5 & 5.0 & 7.1 & 4.0 \\
\hline \multicolumn{5}{|c|}{ Socioeconomic status (self-assessment) (\%) } \\
\hline Bottom 20\% (10) & 11.4 & 4.3 & 11.1 & 3.8 \\
\hline Second 20\% (26) & 11.9 & 5.0 & 10.0 & 3.8 \\
\hline Middle 20\% (44) & 10.0 & 4.7 & 8.0 & 3.7 \\
\hline Fourth 20\% (17) & 9.6 & 4.7 & 6.7 & 3.6 \\
\hline Top 20\% (2) & 10.0 & 5.0 & 6.3 & 3.8 \\
\hline \multicolumn{5}{|l|}{ Beliefs in inequality and pay } \\
\hline \multicolumn{5}{|l|}{ Political affiliation (\%) } \\
\hline Far left (3) & 10.0 & 3.4 & 7.5 & 3.0 \\
\hline Left (17) & 10.0 & 4.0 & 6.7 & 3.2 \\
\hline Central (15) & 12.5 & 5.6 & 10.0 & 4.2 \\
\hline Right (13) & 10.0 & 5.0 & 6.0 & 3.3 \\
\hline Far right (2) & 9.2 & 4.0 & 8.0 & 3.2 \\
\hline \multicolumn{5}{|c|}{ Differences in income in <country> are too large. (\%) } \\
\hline Strongly agree (45) & 12.5 & 4.7 & 10.0 & 3.6 \\
\hline Agree (38) & 10.0 & 4.8 & 7.5 & 3.8 \\
\hline Neither agree nor disagree (8) & 7.1 & 4.2 & 5.8 & 3.4 \\
\hline Disagree (5) & 7.5 & 5.0 & 5.5 & 3.8 \\
\hline Strongly disagree (1) & 6.7 & 4.8 & 6.0 & 4.0 \\
\hline \multicolumn{5}{|l|}{ You earn $<\ldots$.. $>$ than you deserve. $(\%)$} \\
\hline Much less (16) & 11.7 & 4.2 & 10.0 & 3.3 \\
\hline Less (36) & 10.0 & 4.3 & 8.0 & 3.3 \\
\hline What I deserve (34) & 10.0 & 5.0 & 7.5 & 4.0 \\
\hline More (2) & 10.0 & 5.0 & 6.8 & 4.0 \\
\hline Much more (1) & 12.5 & 5.6 & 10.0 & 4.0 \\
\hline
\end{tabular}


How much responsibility goes with the job - how important do you think that ought to be in deciding pay? (\%)

Essential (27)

11.7

10.0

Very important (51)

Fairly important (18)

Not very important (2)

Not important at all $(<1)$
10.0

10.0

10.0

$$
5.0
$$

4.8

4.0

4.4

4.2
9.0

8.0

7.8

8.3

10.0
4.0

3.8

3.3

3.3

3.1

How well he or she does the job - how important should that be in deciding pay? (\%)

Essential (30)

Very important (49)

Fairly important (15)

Not very important (2)

Not important at all $(<1)$
10.0

10.0

10.0

8.0

8.8
5.0

5.0

4.0

3.5

4.2
8.6

8.0

7.5

6.7

7.7

3.8

3.8

3.3

3.3

How hard he or she works at the job? - how important should that be in deciding pay? (\%)

Essential (28)

Very important (49)

Fairly important (19)

Not very important (3)

Not important at all (1)
10.0

10.0

10.0

10.0

11.7
4.8

5.0

4.4

4.6

5.0
9.4

8.1

7.5

6.7

7.5
3.8

3.8

3.3

3.3

3.5 
Figure 1a. Estimated and ideal pay ratios of CEOs to unskilled workers in $\mathbf{4 0}$ countries.

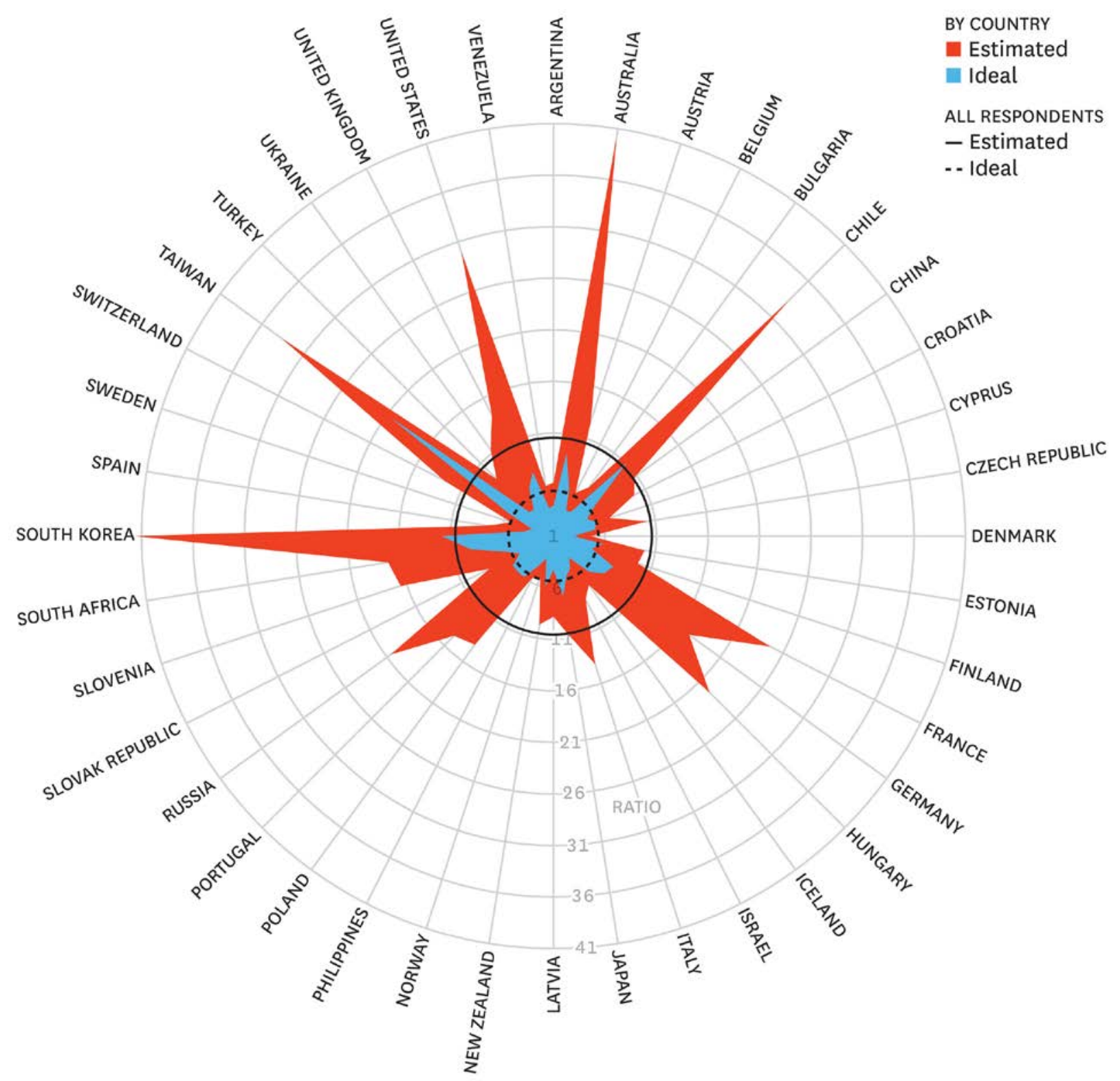

Note. Countries are arranged in alphabetical order. The center of the diagram represents a pay ratio of $1: 1$ (i.e., equal pay); the outermost ring represents a pay ratio of $41: 1$. Red indicates the estimated pay ratio by respondent country; blue indicates the ideal pay ratio by respondent country. The solid black line represents the estimated pay ratio (i.e., 10.0:1) across all respondents; the dotted black line represents the ideal pay ratio (i.e., 4.6:1) across all respondents. 
Figure 1b. Estimated and ideal pay ratios of cabinet ministers to unskilled workers in 40 countries.

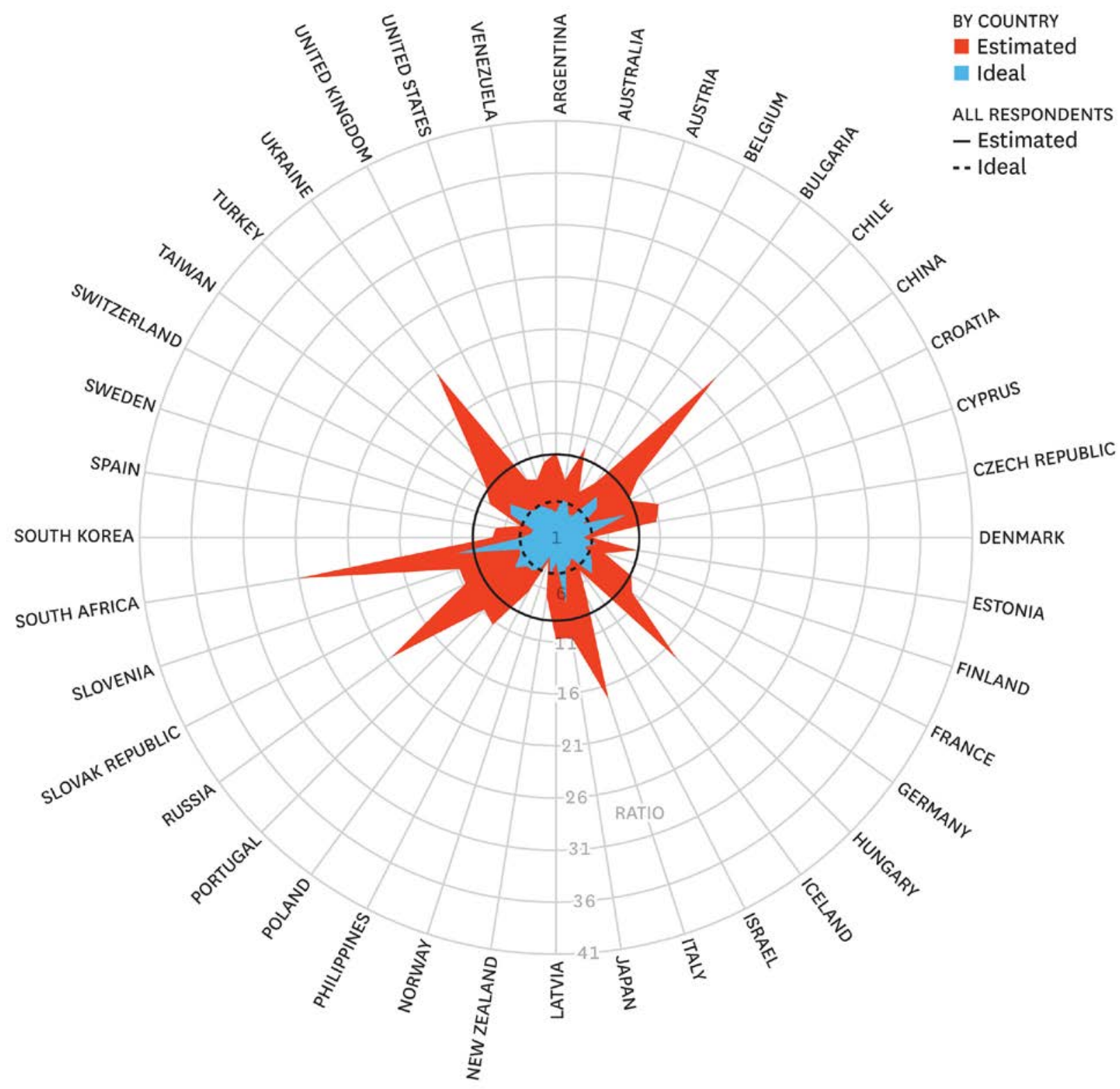

Note. Countries are arranged in alphabetical order. The center of the diagram represents a pay ratio of 1:1 (i.e., equal pay); the outermost ring represents a pay ratio of $41: 1$. Red indicates the estimated pay ratio by respondent country; blue indicates the ideal pay ratio by respondent country. The solid black line represents the estimated pay ratio (i.e., 8.3:1) across all respondents; the dotted black line represents the ideal pay ratio (i.e., 3.6:1) across all respondents. 
Figure 2. Actual, estimated and ideal pay ratios of CEOs to unskilled workers in 16 countries.

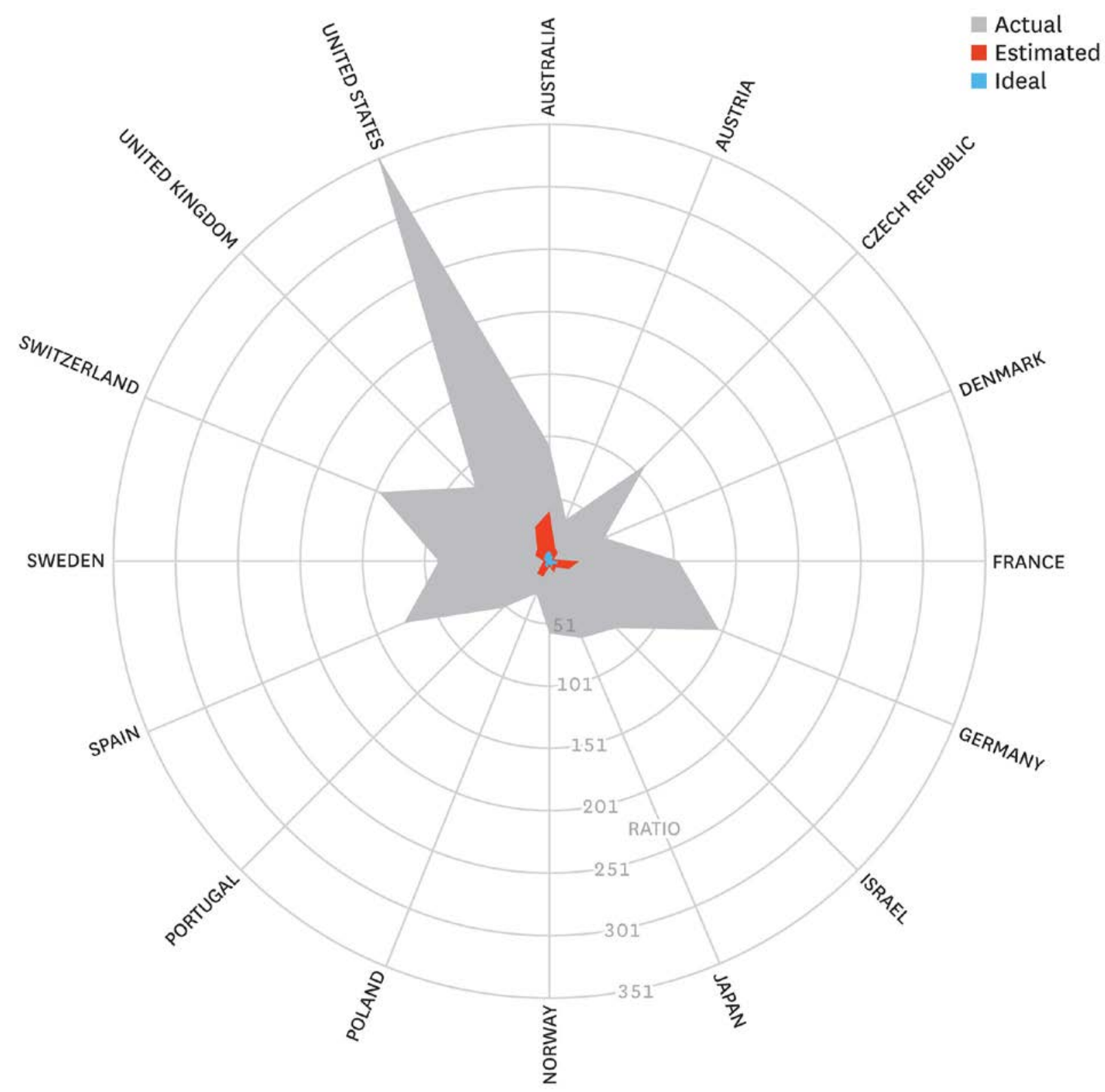

Note. Figure 2 includes the estimated (red) and ideal (blue) data from Figure 1a, but estimates and ideals are so much smaller than actual pay ratios that they are nearly invisible. Countries are arranged in alphabetical order. The center of the diagram represents a pay ratio of 1:1 (i.e., equal pay); the outermost ring represents a pay ratio of 351:1. Red indicates the estimated pay ratio by respondent country; blue indicates the ideal pay ratio by respondent country; gray indicates the actual pay ratio by country. 